\title{
PENGEMBANGAN APLIKASI PERKALIAN DALAM MENINGKATKAN PEMAHAMAN KONSEP DASAR PERKALIAN SISWA SD
}

\author{
Wina Winarti ${ }^{1}$, Luthfi Hamdani Maula ${ }^{2}$, Astri Sutisnawati ${ }^{3}$ \\ ${ }^{123}$ PGSD FKIP Universitas Muhammadiyah Sukabumi \\ 1'winawinarti@ummi.ac.id, 2luthfihamdani@gmail.com, 3astri212@ummi.ac.id
}

\begin{abstract}
In the fact, multiplication is addition operation that has been learned from low grades, but it turns out that not a few students in high grade are still less fluent in operating multiplication. This is one of the reason for conducting this research, the purpose in this study was to find out how feasible application of the multiplication that has developed, and to find out whether application of the multiplication could improve elementary school students in learning mutliplication. This study uses the Reasearch \& Development (R\&D) method. Analysis of the data used is descriptive analysis. The results show that the ability of students to understand concepts has increased after using the application in learning as evidenced by the results of test analysis with gain-score values, in the first and second stages of the trial, the medium category was 0,57 and the second stage of the trial was 0,59. Based on this, it can be interpreted that students agree that learning by using application of the multiplication can help increasing understanding of concepts.
\end{abstract}

Keywords: multiplication operation, students, research \& development, concept understanding

\begin{abstract}
ABSTRAK
Pada hakikatnya perkalian merupakan oprasi penjumlahan yang dilakukan secara berulang yang sudah dipelajari dari kelas rendah, namun ternyata tidak sedikit peserta didik di kelas tinggi masih ada yang kurang lancer dalam mengoprasikan perkalian. Hal itu merupakan salah satu alasan penelitian dilakukan. Penelitian ini memiliki tujuan agar mengetahui kelayakan aplikasi perkalian yang sedang dikembangkan, bagaimana siswa merespon aplikasi perkalian dan mengetahui apakah aplikasi perkalian dapat memberikan peningkatan pada siswa sekolah dasar terhadap materi perkalian. Metode yang digunakan dalam penelitian ini ialah metode Research \& Development (R\&D). Analisis deskriptif digunakan untuk menganalisis data yang diperoleh. Kemampuan pemahaman konsep siswa mengalami peningkatan setelah digunakan aplikasi perkalian daam belajar dibuktikan dengan adanya hasil analisis tes dengan nilai gain-score, pada uji coba tahap 1 diperoleh kategori sedang yaitu dengan hasil 0,57 serta 0,59 yang diperoleh dari uji coba pada tahap ke 2. Berdasarkan hal tersebut dapat diartikan bahwa peserta didik setuju bahwa pembelajaran dengan menggunakan aplikasi perkalian dapat membantu dalam meningkatkan pemahaman konsep.
\end{abstract}


Kata Kunci: operasi perkalian, peserta didik, research \& development, pemahaman konsep

\section{A. Pendahuluan}

Teknologi

merupakan

perkembangan dari ilmu pengetahuan yang telah masuk ke tahap digital dalam dunia pendidikan (Lestari, 2018). Adanya tuntutan zaman terhadap pendidikan mengharuskan terciptanya reformasi mulai dari sistem pendidikan hingga proses pembelajarannya. Pendidikan merupakan faktor penting untuk meningkatkan kecerdasan, kualitas hidup dan juga merupakan suatu kewajiban yang harus ditunaikan oleh setiap orang. Pendidik dituntut memiliki jiwa yang kreatif dan inovatif dalam memanfaatkan perkembangan teknologi yang pesat. Said (2017) mengatakan bahwa dalam kegiatan belajar mengajar yang menganut pembelajaran aktif, kreatif, efektif dan menyenangkan, sehingga guru tidak dapat melepas diri dari media pembelajaran.

Menurut Kusmawati (2017) matematika memiliki peran penting dalam pendidikan dan kehidupan masyarakat. Banyak peserta didik yang menganggap jika pembelajaran matematika sangat sulit dan rumit, hal tersebut dikarenakan banyaknya cara untuk menyelesaikan permasalahan dalam kehidupan sehari-hari yang menggunakan perhitungan (Anggraini et al., 2020). Hal tersebut dapat disebabkan dari penggunaan strategi dalam proses pembelajaran kurang sesuai, sehingga peserta didik merasa jenuh ketika proses belajar berlangsung. Mata pelajaran matematika merupakan suatu komponen yang sangat penting untuk dipelajari dan dikuasai oleh anak-anak hingga orang dewasa, karena sering diaplikasikan dalam kehidupan seharihari (Nuraeni et al., 2020). Maka dari itu diperlukan inovasi pembelajaran yang menarik dan meningkatkan minat belajar peserta didik, sehingga matematika tidak lagi dianggap sebagai mata pelajaran yang sulit dan membosankan serta menakutkan. Sebab mata pelajaran matematika merupakan pelajaran yang sangat penting dan harus dikuasai mulai dari anak-anak hingga orang dewasa

Salah satu materi matematika yang dianggap sulit yaitu oprasi hitung perkalian. Menurut Heruman (2013:30) mengatakan bahwa pada hakikatnya perkalian merupakan 
Pendas : Jurnal IImiah Pendidikan Dasar

ISSN Cetak : 2477-2143 ISSN Online : 2548-6950

Volume VI Nomor 02, Desember 2021

oprasi penjumlahan yang dilakukan secara berulang.

Pada dasarnya perkalian sudah dipelajari dari kelas rendah, namun ternyata tidak sedikit peserta didik di kelas tinggi masih ada yang kurang lancar dalam mengoprasikan perkalian karena kurang memahami materi yang disampaikan. Pemahaman merupakan ilmu dasar yang harus dimiliki oleh peserta didik, karena dengan pemahaman konsep peserta didik dapat mengolah materi yang diberikan berdasarkan pengalaman belajar yang didalamnya terjadi proses penyerapan dan pemahaman serta menerima suatu gagasan sehingga pembelajaran lebih bermakana (Tsabit et al., 2020). Maka dari itu perlu adanya yang dapat membantu peserta didik dalam belajar memahami konsep, menarik, meningkatkan minat belajar peserta didik dan membuat belajar matematika menjadi tidak bosan.

Mengingat anak sekolah dasar pada umunya berusia 6-12 tahun, menurut Piaget mengatakan bahwa anak pada tahap ini (6-12 tahun) mempunyai pengembangan kognitif oprasional konkrit ialah otaknya yang telah mampu beroprasi dengan baik, khususnya mengenai semua benda yang nyata (konkrit) (Kartikasari \&

Rahmawati, 2018). Adanya perkembangan teknologi yang pesat, pendidik dapat memanfaatkannya dan membuat inovasi-inovasi serta meningkatkan suatu kreatifitas, sehingga dapat membuat sebuah media pembelajaran yang menarik baik dalam bentuk audio, visual dan audio visual. Contoh perkembangan dibidang teknologi yang dapat membantu meringankan pembelajaran berupa media adalah multimedia.

Adanya multimedia, pendidik dapat memberikan gambar dengan suara (Video) lebih banyak objek dalam proses pembelajaran. Salah satu multimedia yang dapat digunakan dalam membantu pembuatan aplikasi pembelajaran adalah aplikasi Adobe Animate CC. Adobe Animate CC merupakan perangkat lunak yang dikembangkan dari Adobe Flash. Adobe mengembangkan Flash sehingga merubah nama menjadi Adobe Animate. Menurut Saputro (2018:5-6) mengatakan bahwa media Adobe Animate CC ialah pembbaruan dari Adobe Flash CS 6 yang dibuat dan dikembangkan oleh perusahaan Adobe. Adanya Adobe Animate ini 
Pendas : Jurnal IImiah Pendidikan Dasar

ISSN Cetak : 2477-2143 ISSN Online : 2548-6950

Volume VI Nomor 02, Desember 2021

merupakan penyempurna dari

perangkat yang ada dalam Adobe

Flash, seperti mendukung dalam

pengembangan web yang berbasis

HTML 5 sehingga aplikasi yang dibuat

dapat dikontrol oleh pengguna.

Dalam Adobe Animate terdapat fitur-fitur yang mendukung dalam pembuatan aplikasi pembelajaran, seperti penggunaan actionscript yang berfungsi untuk mempermudah dalam pembuatan animasi. Fitur yang ada dalam Adobe Animate lebih spesifik dan mudah untuk diaplikasikan karena perangkat ini merupakan bentuk penyempurnaan dari Adobe yang ada sebelumnya.

Melihat kondisi pada saat ini banyak peserta didik yang sudah mengenal gawai/smartphone, maka aplikasi yang dibuat dapat dioprasikan melalui smartphone. Adanya aplikasi pembelajaran yang dapat diakses melalui smartphone dapat mempermudah peserta didik karena bersipat fleksibel yaitu bisa dibuka kapan pun dan dimana pun sehingga akan meningkatkan minat belajar peserta didik (Anggraini et al., 2020). Berdasarkan permasalahan yang telah dijabarkan diatas secara runtut dan jelas, maka diperlukan media berupa aplikasi perkalian. Aplikasi tersebut dirancang dengan menggunakan actionscrept pada aplikasi Adobe Animate. pengembangan aplikasi ini bertujuan untuk memberikan kemudahan kepada peserta didik dalam belajar perkalian serta tidak merasa bosan karena dalam aplikasi tersebut terdapat fitur-fitur yang menarik serta pengoprasian aplikasi tersebut dapat dikontrol oleh pengguna. Aplikasi perkaliam diharapkan dapat memberi kemudahan peserta didik dalam mengeri dan mengingat perkalian dengan cepat. Adapun tujuan dari penelitian yaitu untuk mengetahui bagaimana kelayakan aplikasi perkalian yang dikembangkan, bagaimanakan respon siswa terhadap aplikasi perkalian yang dikembangkan, dan mengetahui apakah aplikasi perkalian dapat memberikan peningkatan pada siswa sekolah dasar dalam belajar perkalian. Selain itu, manfaat dilakukan penelitian ini ialah untuk meningkatkan pengetahuan dan mempermudah perkalian untuk peserta didik di tingkat sekolah dasar.

\section{B. Metode Penelitian}

Penelitian ini dilakukan di SDN Babakan Sirna dan SDN 
Muhammadiyah 1 Sukaraja. Sampel

yang digunakan yaitu siswa dikelas 2 .

Metode yang digunakan ialah R\&D

(Research and Development) dari

Brong dan Gall yang diadaptasi.

Adapun Langkah pada penelitian ini di antaranya yaitu menganalisis potensi dan masalah, proses pengumpulan data, desaian produk, validasi desain produk, revisi desain (oleh validator dan praktisi) dan uji coba produk. Teknik yang digunakan dalam penelitian ini yaitu angket berupa lembar validasi media, lembar validasi materi, tes dan angket respon peserta didik serta dokumentasi.

\begin{tabular}{lcc}
\hline \multicolumn{1}{c}{ Rumus } & Klasifikasi & Kategori \\
\hline $\mathrm{X}>\bar{x}_{\mathrm{i}}+1,8 \times \mathrm{sb}_{\mathrm{i}}$ & Sangat Baik & $\mathrm{A}$ \\
\hline $\bar{x}_{\mathrm{i}}+0,6 \times \mathrm{sb}_{\mathrm{i}}<\mathrm{X} \leq$ & Baik & $\mathrm{B}$ \\
$\bar{x}_{\mathrm{i}}+1,8 \times \mathrm{sb}_{\mathrm{i}}$ & & \\
\hline$\overline{\bar{x}}_{\mathrm{i}}-0,6 \times \mathrm{s}_{\mathrm{i}}<\mathrm{X} \leq$ & Cukup & $\mathrm{C}$ \\
$\overline{\bar{x}}_{\mathrm{i}}-0,6 \times \mathrm{s}_{\mathrm{i}}$ & & \\
\hline$\overline{\bar{x}}_{\mathrm{i}}-1,8 \times \mathrm{s}_{\mathrm{i}}<\mathrm{X} \leq$ & Kurang & $\mathrm{D}$ \\
$\overline{\bar{x}}_{\mathrm{i}}-0,6 \times \mathrm{s}_{\mathrm{i}}$ & & \\
\hline $\mathrm{X} \leq \overline{\bar{x}}_{\mathrm{i}}-1,8 \times \mathrm{s}_{\mathrm{i}}$ & Sangat & $\mathrm{E}$ \\
\end{tabular}

Validasi produk pada penelitian ini menggunakan skala likert. Skala likert dengan 5 pilihan, dapat dilihat melalui tabel sebagi berikut:

Tabel 1 Skala Likert

\begin{tabular}{cc}
\hline Skala Penilaian & Kriteria \\
\hline 1 & Sangat kurang \\
\hline 2 & Kurang Baik \\
\hline 3 & Cukup \\
\hline
\end{tabular}

Volume VI Nomor 02, Desember 2021

\begin{tabular}{c}
\hline 5 \\
Sumber: (Sundayana, 2014)
\end{tabular}

Jenis analisis yang digunakan adalah analisis deskriftif, langkah-langkahnya yaitu:

1. Dimulai dengan mencari nilai ratarata jumlah skor yang di peroleh menggunakan rumus:

$$
x=\frac{\Sigma x}{n}
$$

Keterangan:

$x^{-}=$rata - rata skor

$\mathrm{n}$ = banyaknya validator

$\Sigma x=$ jumlah skor yang didapat

2. Mengkonversi nilai rata-rata menjadi skala lima. Agar data dapat diseskripikan maka data yang diperoleh dikonversikan ke dalam data kulilatif.

Tabel 2 Konversi Skor Menjadi Skala Lima Validasi Media

Keterangan:

$X=$ Perolehan Skor

$\bar{x}_{i}=$ Rata-rata skor ideal $\left(\frac{1}{2}\right.$ (Skor maksimal+ Skor minimal))

Sumber: (Widoyoko, 2017)

$s b_{i}=\frac{1}{6}$ (Skor maksimal ideal - Skor minimal ideal)

Skor maksimal ideal $=\Sigma$ Butir kriteria $\mathrm{x}$ Skor tertinggi

Skor terendah ideal $=\Sigma$ Butir kriteria $\mathrm{x}$ Skor terendah

\section{Analisis Respon Peserta Didik}

Peserta didik diberi berupa lembar angaket untuk mengetahui respon 
terhadap aplikasi perkalian dan diberikan setelah menggunakan media pembelajaran yang dibuat. Angket respon peserta didik menggunakan skala Likert dengan 5 (lima) dengan pilihan jawaban yaitu sangat setuju (SS), setuju (S), raguragu $(\mathrm{R})$, tida setuju (TS), dan sangat setuju (SS), sehingga memerlukan analsisi yang baik.

Kemudian untuk membandingkang hasil akhir dengan tabel kriteria interpretasi skor berikut:

Tabel 3 Konversi Persentase Angket

Skala Likert

\begin{tabular}{lll}
\hline No. & Persentase & Kategori \\
\hline $0-20 \%$ & Sangat Lemah \\
\hline $21 \%-40 \%$ & Lemah \\
\hline $41 \%-60 \%$ & Cukup \\
\hline $61 \%-80 \%$ & Kuat \\
\hline $81 \%-100 \%$ & Sangat Kuat \\
\hline \multicolumn{2}{l}{ Sumber: (Riduwan, 2019) }
\end{tabular}

\section{Analisis Pre-Test dan Post-Test}

Teknik analisis data dilakukan untuk mengetahui tingkat kemampuan pemahaman konsep perkalian peserta didik dan keefektifan produk pengembangan yang di uji coba dalam pembelajaran. Pengujian dilakukan dengan membandingkan data pre-test dan post-test dengan menggunakan uji n-gain atau gain score, rumusnya yaitu:
Gain Score

$$
=\frac{\text { Skor posttest }- \text { skor prettest }}{\text { Skor maksimum - skor prettest }}
$$

Tabel 4 Kriteria Peningkatan Hasil

Belajar

\begin{tabular}{cc}
\hline $\begin{array}{c}\text { Nilai gain } \\
\text { Ternormalisasi }\end{array}$ & Interpretasi \\
\hline$-1,00 \leq \mathrm{g}<0,00$ & Terjadi penurunan \\
\hline $\mathrm{G}=0,00$ & Tetap \\
\hline $0,00<\mathrm{g}<0,30$ & Rendah \\
\hline $0,30 \leq \mathrm{g}<0,70$ & Sedang \\
\hline $0,70 \leq \mathrm{g}<1,00$ & Tinggi \\
\hline \multicolumn{2}{l}{ Sumber: (Sundayana, 2018) }
\end{tabular}

\section{Hasil Penelitian dan \\ Pembahasan}

\section{Kelayakan Aplikasi Perkalian}

Produk yang dikembangan pada penelitian ini adalah media pembelajaran berupa aplikasi perkalian yang dapat dioprasikan melalui smartphone/HP. Sebelum diterapkan dalam pembelajaran, media yang dikembangkan harus dinyatakan layak terlebih dahulu. Untuk mendapatkan kelayakan pada media yang dikembangkan harus melalui tahap validasi atau penlaian kelayakan oleh validator. Tahap validasi media ini dilakukan oleh ahli media, ahli materi dan praktisi. Adapun aspek penilaian dalam kelayakan media ini diantaranya komponen kualitas kelayakan isi, komponen kualitas intruksional dan 
Pendas : Jurnal IImiah Pendidikan Dasar

ISSN Cetak : 2477-2143 ISSN Online : 2548-6950

Volume VI Nomor 02, Desember 2021

komponen kualitas teknis (Arsyad, 2013). Penilaian komponen kelayakan isi diberikan oleh ahli materi dan praktisi dalam menilai materi yang pemahaman konsep perkalian dalam aplikasi yang dikembangkan.

Terdapat 7 indikator dalam komponen kelayakan isi yaitu ketepatan, kepentingan, kelengkapan, keseimbangan, minat/perhatian, keadilan dan kesesuaian dengan situasi peserta didik. Validasi dapat dilakukan beberapa kali tergantung pada perbaiakan atau saran yang diberikan oleh validator hingga materi yang diajukan dinyatakan layak digunakan. Untuk mengetahui klasifikasi dan kategori, maka dilakukan analisis hasil skor yang diperoleh dari angket penilaian validator. Hasil analisis angket untuk komponen kelayakan isi dan tujuan oleh ahli didapatkan jumlah 27 dengan kategori B dan kalsifikasi baik. Sementara jumlah skor yang diperoleh pada angket hasil penilaian praktisi adalah 30 dengan kategori $\mathrm{A}$ dan klasifikasi sangat baik.

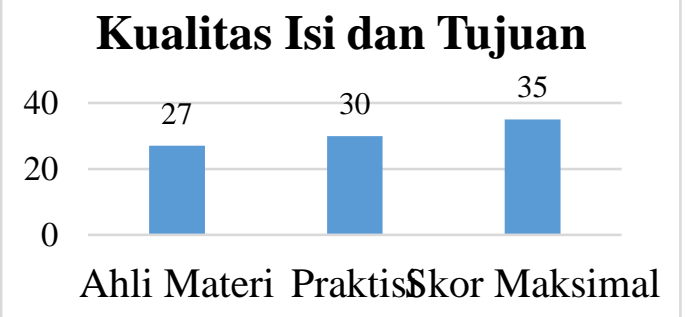

\section{Tujuan Ahli dan Praktisi}

Kemudian pada komponen intruksional dilakukan oleh ahli media dan praktisi yang menilain dalam media yang dikembangkan yaitu aplikasi perkalian. Perolehan skor dari ahli media yaitu 30 termasuk dalam kategori A dan klasifikasi sangat baik. kemudian skor perolehan dari praktisi yaitu 32,5 dengan kategori $\mathrm{A}$ dan klasifikasi sangat baik.

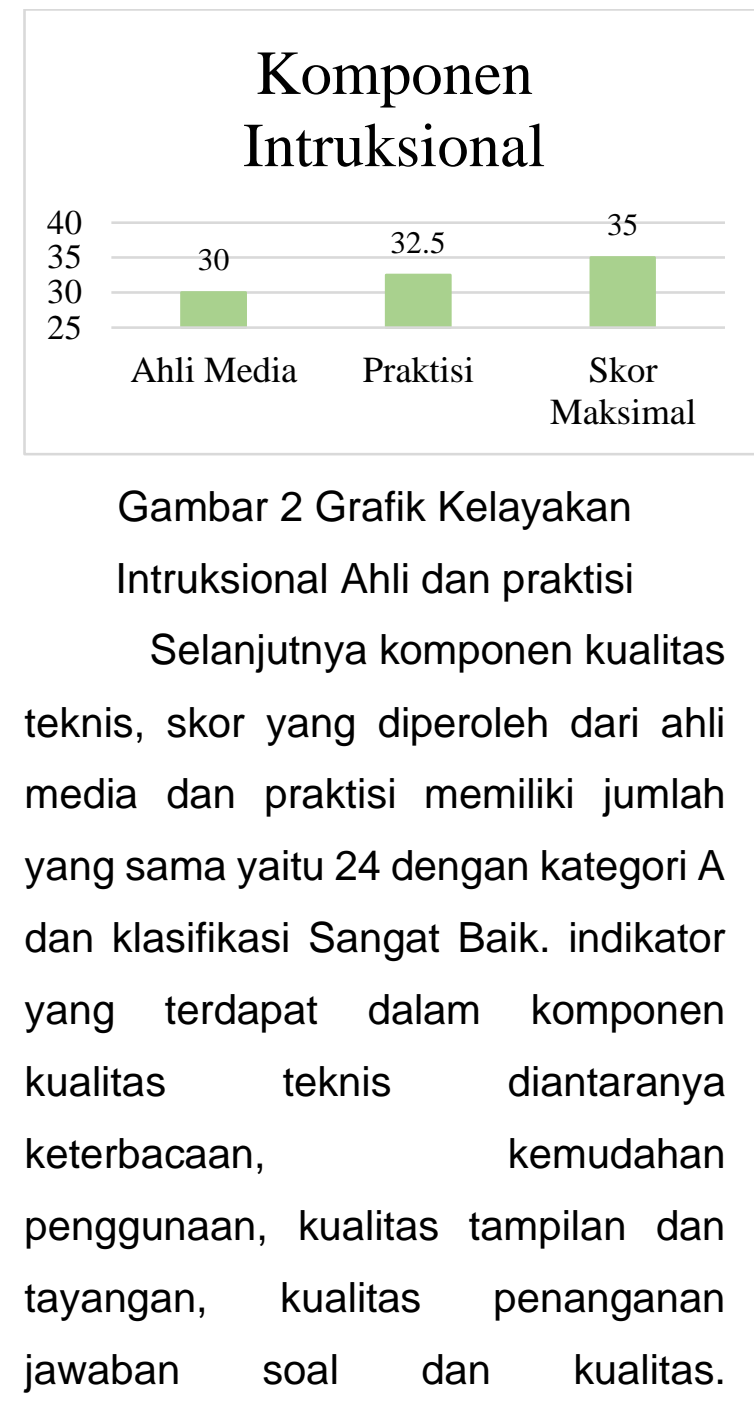


penanganan program.

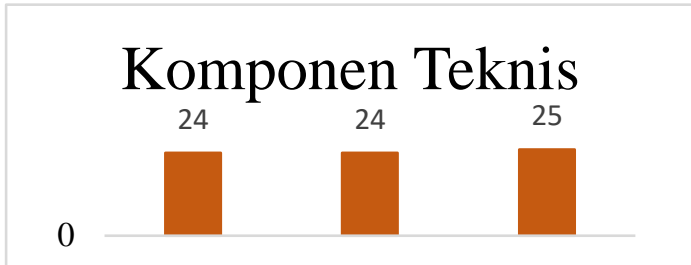

Ahli Media Praktis\$kor Maksimal

Gambar 3 Grafik Kelayakan Teknis

$$
\text { Ahli dan Praktisi }
$$

Berdasarkan skor akhir perolehan dari validasi ahli dan praktisi, bisa diartikan bahwa aplikasi yang dikembangkan dinyatakan layak untuk digunakan pada penelitian dengan kriteria yang telah dijelaskan. Hal tersebut karena produk penelitian dibuat sesuai dengan indikator menurut Walker dan Hess dalam (Arsyad, 2013). Selain materi yang disampaikan, dalam media pembelajaran hasil pengembangan ini juga mengutamakan efek visualnya berupa animasi.

\section{Pemahaman Konsep Perkalian}

Setelah melakukan validasi produk oleh ahli dan praktisi hingga dinyatakan layak digunakan, kemudian produk dilakukan uji coba pada peserta didik. Uji coba dilakukan sebanyak dua kali, yaitu uji coba pertama dilakukan dengan 10 orang peserta didik dan uji coba kedua dengan 15 peserta didik dari SDN
Babakan Sirna. Uji coba pertama dilakukan di kediaman salah satu peserta didik, hal itu dikarenakan sedang kondisi dan situasi kurang mendukun. Namun pada uji coba kedua dilakukan di sekolah atas izin dan persetujuan dari wali kelas dan wali murid. Uji coba tersebut bertujuan untuk mengetahui peningkatan pemahaman konsep dasar perkalian setelah peserta didik setelah menggunakan aplikasi perkalian. Sebelum aplikasi perkalian digunakan pada pembelajaran, peserta didik terlebih dahulu diberikan pret-test. Kemudian setelah peserta didik melalui pret-test barulah diterapkan penggunaan aplikasi perkalian dalam proses pembelajaran. Peserta didik sangat semangat dan antusias dalam mengikuti pembelajaran serta menjadi lebih fokus dalam memahami materi serat pembelajaran lebih menyenagkan karena penggunaan aplikasi dapat disesuaikan berdasarkan kebutuhan peserta didik dan penyampaian materi menggunakan video pembelajaran yang menarik.

Berdasarkan penjelasan tersebut, hasil kemampuan pemahaman konsep perkalian dapat diketahui melalui analisis dari hasil pre-test dan 
post-test yang dilakukan pada tahap uji coba. Soal yang diberikan kepada peserta didik terdiri dari 10 soal yang disesuaikan dengan indikator pemahaman konsep. Penggunaan aplikasi perkalian ini dilakukan setelah pret-test dan sebelum post-test. Setelah dilakukan pret-test dan posttest maka diperoleh hasil data dari masing-masing peserta didik yang kemuadian dianalisis dan diolah menggunakan rumus $\mathrm{N}$-gain. Pengolahan data tersebut bertujuan untuk mengetahui sejauh mana kemapuan pemahaman konsep perkalian peserta didik serta mengetahui apakah terjadi peningkatan, sama saja atau bahkan terjadi penurunan stelah pembelajaran menggunakan aplikasi perkalian yang dikembangkan. Hasil analisis data penilaian pret-test dan post-test terjadi peningkatan. Pada uji coba tahap 1 diperoleh rata-rata skor pret-tes yaitu 65,3 dan rata-rata skor posttest 85,5 . Sedangkan pada uji coba tahap 2 rata-rata skor pre-test ialah 64,5 dan rata-rata skor posttest 85,8 .

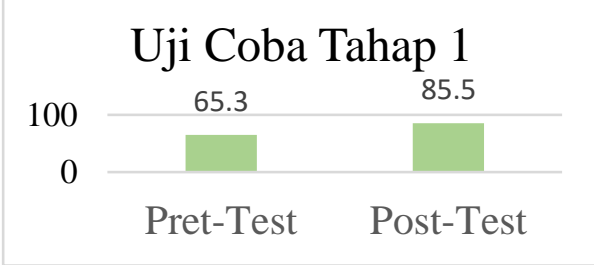

Gambar 4 Uji Coba Tahap 1 Prettes -

Posttest

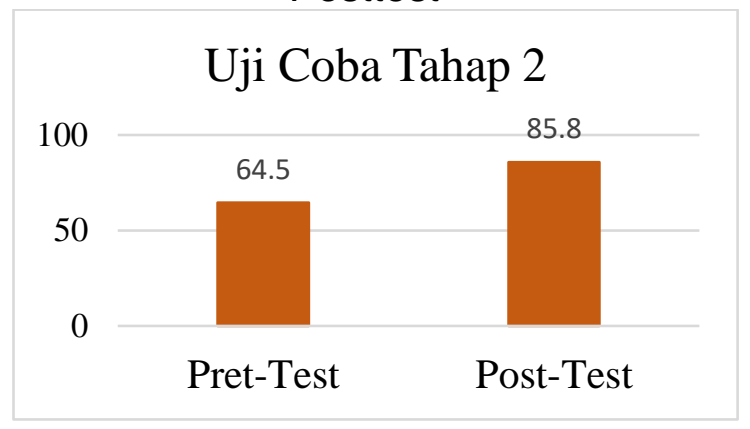

Gambar 5 Uji Coba Tahap 2 Pret-

Test dan Post-Test

Hasil rekapitulasi uji coba tahap 1 dan uji coba tahap 2, pada tahap 1 memiliki skor rata-rata 0,57 yang termasuk kedalam kategori sedang dan uji coba tahap 2 diperoleh ratarata skor sebesar 0,59 yang termasuk kedalam kategori sedang.

\section{Analisis Pret-Test dan Post-} Test

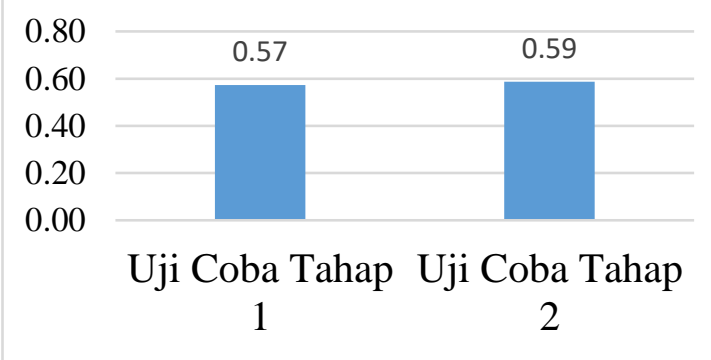

Gambar 6 Analisis Pret-Test dan

Post-Test Uji Coba 1 dan 2

Berdasarkan gambar di atas dapat ditarik kesimpulan bahwa pemahaman konsep perkalian peserta didik mengalami peningkatan dengan kategori sedang. Pembelajaran matematika sering dianggap sulit, salah satu materi yang dianggap sulit 
Pendas : Jurnal IImiah Pendidikan Dasar

ISSN Cetak : 2477-2143 ISSN Online : 2548-6950

Volume VI Nomor 02, Desember 2021

yaitu oprasi perkalian. Namun dengan

adanya aplikasi yang dikembangkan

peserta didik dapat meningkatkan pemahaman materi dengan baik. Hal ini disebabkan karena adanya pembaharuan dalam proses penyamapaian materi sehingga pembelajaran lebih menarik, mamirateri tersampaikan dengan baik dan mendapatkan hasil yang baik. Pemahaman konsep merupakan hal yang penting, menurut Rafia (2013:14) konsep membantu kita dalam mengingat dan membuatnya lebih efesien. Membantu peserta didik yang kesulitan dalam mengingat dan memahami materi terutama oprasin perkalian maka harus adanya inovasi yang membuat pembelajaran lebuh bermakna atau menarik baik secara visual, audio maupun gerak sehingga pemahaman konsep dapat meningkat.

Seperti pada penelitian ini yang mengembangkan sebuah media pembelajaran yang menarik yaitu aplikasi perkalian sehingga dapat meningkatkan pemahaman konsep perkalian peserta didik.

\section{Respon Peserta Didik}

Setelah dilakukan tes dalam rangka untuk mengetahui sejauh mana kemampuan peserta didik dalam pemahaman konsep perkalian, kemudian dilakukan penyebaran

angket. Pada lembar respon peserta didik terdapat beberapa aspek penilaian yaitu komponen kelayakan isi dan tujuan, komponen kualitas intruksional dan komponen kualitas teknis (Arsyad, 2013). Pengisian lembar respon ini dilakukan dua kali karena dilakukan uji coba sebanyak dua kali yaitu uji coba tahap 1 dengan jumalah 10 orang dan uji coba tahap 2 dengan jumlah 15 orang.

Penilaian pada komponen kualitas isi dan tujuan memiliki 7 indikator dengan skor maksimum 35 dan pada uji coba tahap 1 diperoleh skor ratarata yaitu 44,6. Kemudian untuk komponen intruksional juga memiliki 7 indikator dengan skor maksimum 35 dan skor rata-rata yang diperoleh yaitu 41,6. Lalu untuk komponen teknis memiliki 5 indikator dengan nilai maksimum 25 dan skor rata-rata yang diperoleh yaitu 42. Untuk mengetahui persentase dan kategori respon peserta didik, maka dilakukan analisis data menggunakan perhitungan skala likert. Setelah dilakukan analisis data, maka diperoleh persentase dan kategori respon yang diberikan peserta didik pada setiap komponen yaitu kualitas isi dan tujuan $89 \%$, komponen intruksional sebesar $83 \%$ 
dan komponen teknis sebesar $84 \%$. ketiga persentase tersebut menunjukan kategori sangat kuat, apabila persentase tersebut dijumlahkan dan kemudian diperoleh nilai rata-ratanya yaitu $85 \%$ yang menunjukan kategori sangat kuat.

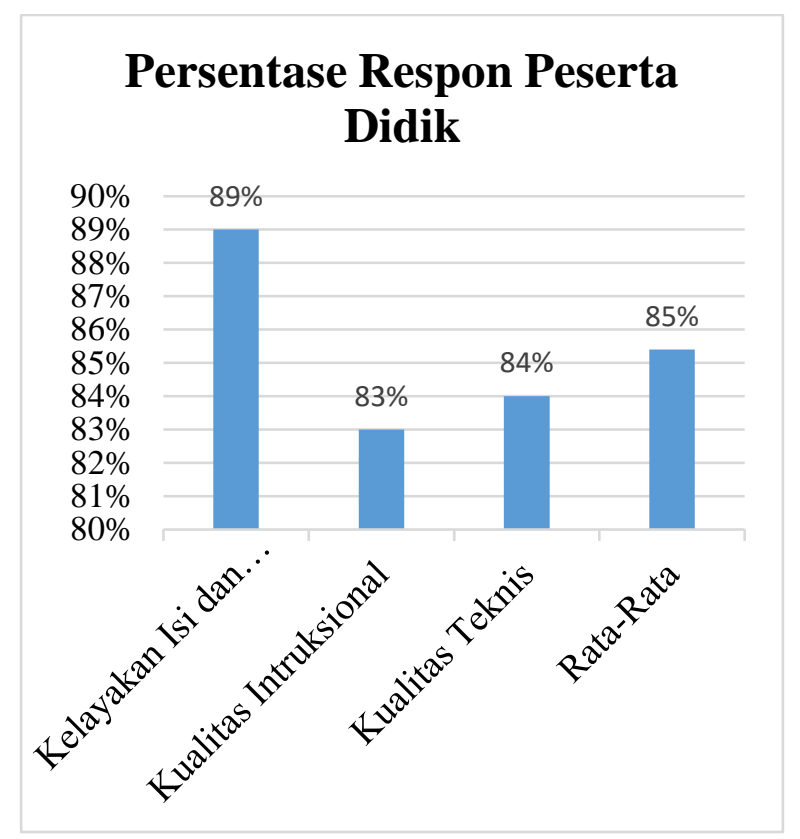

Gambar 7 Persentase Respon

Peserta Didik Uji Coba Tahap 1

Kemudian untuk penilaian respon peserta didik pada uji coba tahap 2 menggunakan lembar respon yang sama denga uji coba 1 . Untuk komponen isi dan tujuan memperoleh skor rata-rata 64,8 dengan persentase $86 \%$, komponen intruksional mendapatkan skor rata-rata 62 dengan persentase $83 \%$ dan komponen teknis memperoleh skor rata-rata 65,8 dengan presentase 88 $\%$.

Volume VI Nomor 02, Desember 2021

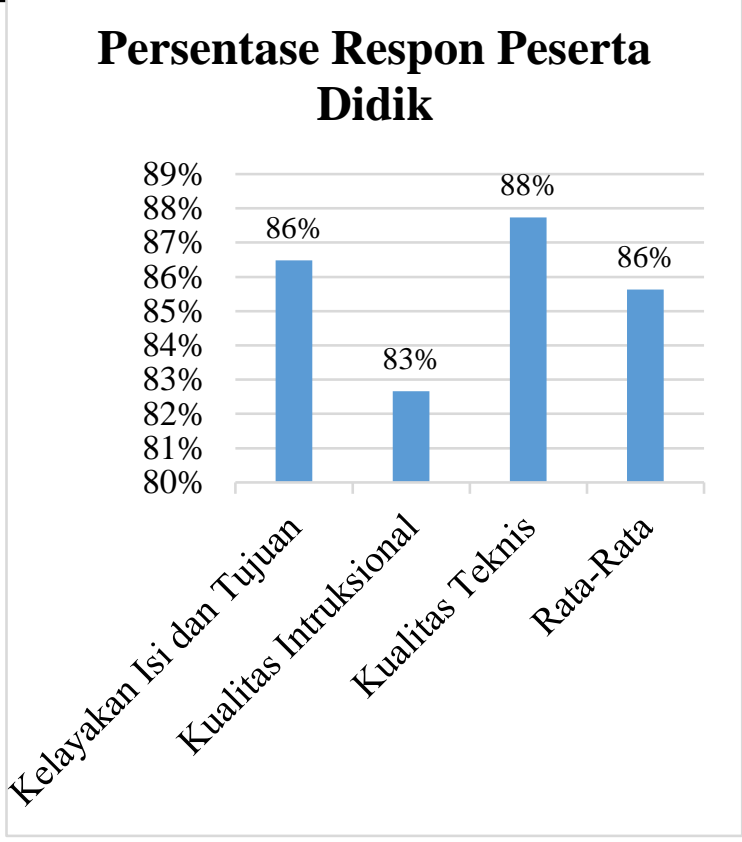

Gambar 8 Persentase Respon

Peserta Didik Uji Coba Tahap 2

\section{Kesimpulan}

Aplikasi perkalian merupakan media yang dikebangkan pada penelitian ini. Kelayakan produk dihasilkan berdasarkan penilaian yang diperoleh dari ahli media, ahli materi dan praktisi. Penilaian oleh ahli dan praktisi kemudian dianalisis pada setiap komponen dan dikategorikan serta digolongkan berasarkan tabel kelayakan produk. Hasil akhir yang diperoleh untuk komponen kelayakan isi dan tujuan yaitu 28,5 dengan kategori B dan kalsifikasi baik, komponen kualitas intruksional yaitu 31,25 dengan kategori $A$ dan klasifikasi sangat baik, dan untuk komponen kualitas teknis diperoleh 
Pendas : Jurnal Ilmiah Pendidikan Dasar

ISSN Cetak : 2477-2143 ISSN Online : 2548-6950

Volume VI Nomor 02, Desember 2021

hasil 24 dengan kategori $A$ dan

klasifikasi sangat baik.

Kemampuan pemahaman konsep peserta didik mengalami peningkatan setelah menggunakan aplikasi dalam belajar. Kegiatan pembelajaran dilakukan dua kali tahapan uji coba dengan menggunakan tes. Peningkatan tersebut dapat dibuktikan dengan adanya hasil analisis tes dengan nilai gain-score, pada uji coba tahap 1 diperoleh 0,57 dengan kategori sedang dan pada uji coba tahap 2 diperoleh 0,59 dengan kategori sedang juga. Maka berdasarkan hal tersebut peserta didik mengalami peningkatan dalam pemahaman konsep perkalian dengan menggunakan aplikasi perkalian yang dikembangkan. Respon peserta didik setelah menggunakan aplikasi perkalian dapat ditunjukan berdasarkan hasil persentase setiap komponen dari skor lembar respon yang telah dianalisis dan diperoleh rata-rata sehingga terlihat persentase pada setiap komponen. Pemberian lembar respon juga dilakukan dua kali, untuk respon pada uji coba 1 diperoleh komponen kelayakan isi dan tujuan $89 \%$, komponen kualitas intruksional $83 \%$ dan komponen kualitas teknis $84 \%$ dengan rata-rata $85 \%$. Ketiga komponen tersebut termasuk kedalam kategori sangat kuat. Kemudian untuk respon peserta didik pada uji coba 2 diperoleh persentase komponen kelayakan isi dan tujuan $86 \%$, komponen kualitas intruksional $83 \%$, dan komponen kualitas teknis $88 \%$ dengan rata-rata $86 \%$. Pada uji coba 2 juga termasuk dalam kategori sangat kuat. Berdasarkan hal tersebut dapat diartikan bahwa peserta didik setuju bahwa pembelajaran dengan menggunakan aplikasi perkalian dapat membantu dalam meningkatkan pemahaman konsep.

\section{DAFTAR PUSTAKA}

Amir, Almira. (2014). Pembelajaran Matematika Dengan Menggunakan Media Manipulatip. Forum pedagogik. 6(01).72-79.

Anggraini, M., Marthasari, G. I., \& Husniah, L. (2020). Aplikasi Media Pembelajaran Operasi Hitung Perkalian Dan Pembagian Berbasis Android. 2(2), 225-238. Arsyad,

A. (2013).

Mediapembelajaran. Rajawali Pers.

Arifah, Ummi \& Abdul Aziz Saefudin. (2017). Menumbuhkembangkan 
Kemampuan Pemahaman

Konsep Matematika Dengan

Menggunakan Model

Pembelajaran Guided

Discovery. Jurnal Pendidikan

Matematika. 5(3):263-272.

Tsabit, D., Amalia, A. R., \& Maula, L.

H. (2020). Analisis Pemahaman

Konsep Ips Materi Kegiatan

Ekonomi Menggunakan Video

Pembelajaran Ips Sistem Daring

Di Kelas IV.3 SDN Pakujajar

CBM. Jurnal IImiah Pendidikan

Dasar, $V$.

Madcoms. (2013). Kupas Tuntas

Adobe Flash Profesional CS6.

Yogyakarta: Andi Publisher.

Kartikasari, A., \& Rahmawati, I.

(2018). Pengembangan Media

Game Moou Train Berbasis

Android Pada Mata Pelajaran

Matematika Materi Perkalian

Untuk Siswa Kelas lii Sd. JPGSD,

06.

Lestari, S. (2018). Peran Teknologi

Dalam Pendidikan Di Era

Globalisasi. Jurnal Pendidikan

Agama Islam, 2(2), 94-100.

Nuraeni, D., Uswatun, D. A., \&

Nurasiah, I. (2020). Analisis

Pemahaman Konsep Kognitif

Matematika Materi Sudut

Menggunakan Video pembelajaran Matematika Sistem

Daring Di Kelas IV B SDN

Pintukisi. Jurnal IImiah

Pendidikan Dasar, V, 61-75.

Riduwan. (2019). Skala Pengukuran

Variabel-Variabel Penelitian.

Alfabeta.

Sundayana. (2014). Media dan alat peraga. Alfabeta.

Sundayana. (2018). Statistika

Penelitian Pendidikan. Alfabeta.

Sugiyono. (2015). Metodologi

penelitian pendidikan. Bandung:

Alfabeta

Widoyoko, E. P. (2017). Evaluasi

Program Pembelajaran. Pustaka

Pelajar. 